\title{
Analysis of Developers of Online Courses on Ukrainian Platforms of MOOC
}

\author{
https://doi.org/10.3991/ijet.v16i05.18581 \\ Sergii Sharov $(\square)$ \\ Bogdan Khmelnitsky Melitopol State Pedagogical University, \\ Melitopol, Ukraine \\ sharov@mdpu.org.ua \\ Anatolii Pavlenko \\ Khortytsia National Educational and Rehabilitation Academy, \\ Zaporizhzhia, Ukraine \\ Tetiana Sharova, Olga Chorna \\ Bogdan Khmelnitsky Melitopol State Pedagogical University, \\ Melitopol, Ukraine
}

\begin{abstract}
The article examines the developers of courses on Ukrainian platforms of massive open online courses Prometheus, EdEra, Open University of Maidan, their quantitative analysis in various thematic areas. It is noted that education remains the main way to acquire new knowledge and form the necessary competencies. The main advantages of open educational resources, their classification, the reasons for the growing popularity in modern society are highlighted. It was found that massive open online courses are a logical continuation of distance learning courses, have their differences and features. However, some problematic issues related to the promotion of massive open online courses that need to be addressed are considered. An analysis of the number of online courses on Ukrainian-language platforms and their thematic areas. As of March 2020, there are 235 online courses on all considered platforms. The same topics for all platforms were law, training, education, media, economics, health. It was found that the most active developers of online courses on the platform of the Open University of Maidan were public and charitable organizations. Educational online platforms and international organizations are most actively involved in the creation of online courses on the EdEra resource. On the Prometheus platform, the largest number of courses was created at the initiative of international organizations, institutions of higher and secondary education.
\end{abstract}

Keywords-Education, distance learning, developers, massive open online courses 


\section{Introduction}

The use of information and communication technology (ICT) is one of the criteria both for the development of the information society and the development of any state. Recognition of information as one of the main intangible resources has led to its annual exponential increase. As a result, a necessity has arisen to update methods and tools for finding, processing and storing information, as well as to form a modern person who has all the necessary information competencies.

Under the conditions of the world virtual space, information resources act as a public product which is actively used by users, and the access to which is offered without any restrictions. At the same time, the possibilities of interpersonal interaction are changing and e-commerce is spreading. The latter can significantly affect the profits of organizations. Besides, there is a need to adapt educational institutions, teachers, and students to the capabilities of the information society.

Despite the significant technological development of society, education remains the main way to acquire new knowledge and form the necessary competencies. The Internet has significantly affected the system of higher and secondary education and led to the emergence of distance learning courses, massive open online courses (MOOC), electronic textbooks and many other things. New technologies have appeared, such as augmented reality [1], e-learning, m-learning [2], blended learning [3], cloud technologies, etc. Educational electronic resources and educational software allow us to gain access to a variety of educational information, providing users with communication and lifelong learning.

E-learning, which is the basis of distance learning, has manifested itself most in higher education. It provided an opportunity to change approaches to teaching and learning, it offered an individualized schedule for the work of students, it changed the methods, means of control [2] and self-control of knowledge. Today, one can observe an active use of distance learning systems [4] and massive open online courses for the development of professional and general competencies of higher education students, for advanced training of pedagogical specialists [5], and for all those interested. The distance learning systems and massive open online courses are similar in nature and purpose, but they are different in functionality and scope. Whereas the distance learning systems are commonly used within higher education institutions, the massive open online courses provide a greater degree of freedom in the implementation of online education.

The best-known Ukrainian platforms are Prometheus, EdEra, and the Open University of Maidan (OUM). Each of them provides users with a variety of online courses developed by the teachers of leading higher education institutions, international organizations, foundations and others. In this aspect, information about the developers of online courses is useful, since the quality and content of the created online course depends on the developer's reputation and professionalism.

The purpose of the article is to analyze the developers and thematic areas of online courses which are presented on the Ukrainian platforms of massive open online courses such as Prometheus, EdEra, and OUM. It is expected to test the assumption 
that well-known international organizations, government agencies, and higher education institutions are involved in the development of online courses.

\section{Electronic Educational Resources as a Means of Online Education}

\subsection{Significance and types of open educational resources}

The modern information society is characterized by rapid and in-depth processes associated with the production of large amounts of information, the development of new technologies for its processing, storage and transmission, as well as with the creation of appropriate hardware and software capabilities, with the increase of transparency in communication. At the same time, there is a rapid ageing of educational information [6], which is taught at educational institutions, as well as of professional knowledge [7]. Thus, it is necessary to change outdated educational paradigms associated with the accumulation of knowledge, and to generate new approaches aimed at developing the necessary competencies and skills.

Currently in Ukraine one can see that active work is being done at the methodological, legislative and other levels in order to build a modern information society. Among the priority areas, scientists highlight the development and implementation of electronic educational resources in the educational process of higher and secondary school, the improvement of material and technical, as well as scientific and methodological support, the development of information environment at educational institutions, and the improvement of the quality of educational content and ICT [8]. With this in mind, the elements of e-learning and blended learning are actively used in higher education. They allow improving the quality of the educational process and prepare young people for active professional and social activities in the information society.

Also, it is important to train future professionals how to search and critically interpret information. It is necessary to develop future professionals' flexibility while choosing the best tools and methods for solving educational and professional problems. Also, it is important to form their ability to solve problems in a creative way [6]. On the other hand, teachers must also adapt to the virtual educational environment, combining traditional and digital technologies in teaching [9] for their own development and self-development.

It should be noted that it is appropriate to use ICT in various forms of educational activities. Thus, during lectures and laboratory work ICT provide clarity in presentation of educational material, they provide control of educational achievements, acquisition of new knowledge, and development of relevant competencies. Computerized teaching aids and educational resources give students a possibility to work with educational material independently. In addition, the use of ICT gives a cumulative effect due to a combination of several advantages: strengthening the creative activity of the individual owing to a reasonable selection of educational tasks; comprehensive consideration of educational topics through the use of information from various sources 
[10]; development of competencies while working with information; broadening the horizons through the use of hardware and software.

It should be stressed that in the environment characterized by an active combination of ICT capabilities and traditional forms of learning, as well as the rapid development of the Internet and the globalization of educational processes, open educational resources (OER) have become widespread. Their creation and use is, in fact, a new step towards the formation of a single educational environment that provides free access to educational information and interactive communication between the participants in the learning process.

As a result, the modern educational process actually contains OER as a structural element of distance learning, which is used by students, teachers, and the authorities of educational institutions. At the same time, the popularity of distance learning in higher education is explained by the following objective reasons and advantages:

- The need for a flexible response of higher education to the needs of the information society

- Providing continuous learning and updating of educational information

- Modular principle in the development of training courses [7]

- The ability to work with learning materials in asynchronous mode

- Free choice of online courses and time for their study [11]

- Interactivity of educational activities and feedback support

- Various forms of user knowledge control

- Economic advantages over full-time study at a higher education institution.

Open educational resources include a variety of software, methods and tools that provide access to educational information [12], textbooks, videos, training courses or their individual parts [3]. If we take the functionality of OER as a criterion for their classification, we can identify the following types: training OER (textbooks, electronic textbooks, software and pedagogical tools); educational technique OER (educational programs, profiles of educational programs, curricula, syllabuses of disciplines); methodological OER (thematic plans of lectures, methodological recommendations for laboratory works, self-study work, writing term papers); control OER (software for control and self-control of knowledge in the form of modules or separate computer programs); auxiliary OER (reference books, dictionaries, scientific journals, conference proceedings) [13]

The main advantages of OER include: increase of opportunities for interaction between participants in the learning process; creation of new teaching methodologies based on the use of ICT; emergence of a productive and personalized form of learning [14]; the ability to use OER on various electronic devices; availability of an open license for the use of educational content [12]; ensuring the principle of openness and accessibility of education; dissemination of academic culture and status of the educational institution [15];improving the quality of educational content; significant reduction of time for the creation of educational and methodological support in comparison with traditional educational and methodological resources; free use of educational resources, reducing the cost of their creation and content. 
It should be added that the effectiveness of the OER use in the educational process has been repeatedly confirmed by scientific studies. The generalized information on the impact that e-learning resources make on the quality of education and the attitude of students to them is reflected in the study by J. Hilton III. The author analyzed 16 research works and confirmed the idea of achieving the same learning outcomes at a lower cost. All the analyzed research works were selected according to several criteria: they studied the use of OER as the main learning resource; they were published in peer-reviewed journals; they contained clearly defined results or indicators of OER implementation in the learning process; they had a minimum number of respondents who participated in the experiment [16].

\subsection{Advantages of massive open online courses}

There are many solutions and applications in the software market provided by distance learning. One of the common tools for online education is the Learning Management System, in particular Moodle. Such systems are often used by higher education institutions as the main tool for distance learning. They allow you to store educational material, to monitor academic achievement [17], and provide feedback between students and the teacher. Also, mobile technologies are in demand, which, thanks to modern gadgets, allow you to learn individually at any time.

One of the common OER used to comprehensively support distance learning is massive open online courses (MOOC). In addition to the advantages that are characteristic of distance learning [18], MOOC have the following features: they are massive, partially free, and available [19]; they help to master additional educational material taught at higher education institutions; they help to maintain educational communication between students [20]; the use of MOOC help to improve professional skills [5] and the level of digital competence; they ensure students' self-development on any subject [6].

Unlike regular distance learning courses, MOOC have several significant differences. First, it is the possibility of receiving distance and free education in various fields of human activity in contrast to paid educational services offered to students by higher education institutions. Second, distance courses used at higher education institutions are usually closed to the users who are not students of these institutions. However, any user can simultaneously use MOOC which presents courses on various topics. After taking online courses, as a rule, the users are given a certificate in electronic form, certifying the result of their successful training. In case distance learning is being received at a higher education institution, certificates are not provided.

Despite many benefits of MOOC, there are some issues that need attention and resolution. These include: insufficiently thought-out system of relationship between the developers (lecturers) of courses and students, imperfect assessment of knowledge within the course [21], possession of a certain level of digital literacy, which provides work with open educational resources [22], adherence to academic integrity in the course. Very often there is a situation when the online course is taken by another person who already knows the answers to all the test questions. Also, there is the problem of the certificate recognition by higher education institutions [19]. 
One of the main problems in the use of massive open online courses is the lack of sufficient motivation for students to take courses up to the end, their low selforganization [7], lack of "live" communication with teachers and students, technical problems associated with the display and input of text on digital gadgets [23]. As a result, after registration some students do not complete their tasks or do not enter the online course at all. Researchers include a number of factors that influence the motivation of students to learn through MOOC such as professional identity, satisfaction with learning new things, future economic benefits, development of personal qualities [24], high responsibility and motivation of students to acquire knowledge [25]. If we approach this problem from another angle, we emphasize that open educational resources, including massive open online courses, should be supported by the state and educational institutions [12], the certificates of online courses should be recognized as part of non-formal education [22].

One of the ways to involve students in the use of MOOC is to diversify the topics of online courses and ensure the quality of educational content. It should be noted that there are significant positive changes in both directions, both among the English and Ukrainian educational online platforms. For example, for the preparation of bachelors of computer science the most common are the English online platforms (Coursera, Academy, Udacity) and the Ukrainian (Prometheus) ones [20]. At the same time, there are various online courses for humanitarian training on the Ukrainian platforms. In particular, the EdEra platform can be used to develop the competencies of future teachers of the Ukrainian language and literature [26], specialists in primary education [6] and others. A positive feature of Ukrainian online platforms is the creation of their own educational content with the involvement of leading organizations and institutions of higher education, as well as foreign partners [27].

To ensure the quality of the educational content of the developed online courses, it is important that the course developers and institutions should be grant-makers or sponsors. As for the developers, they are usually teachers of leading higher education institutions (foreign and domestic) [19], who have the opportunity and desire to share their experience with the educational community [22]. In addition, well-known personalities who are not indifferent to education and science in Ukraine join the work as lecturers or test developers. Obtaining a certificate which is signed by a famous person and proves the course completion is success for the students and an opportunity for the online platform to become more popular.

\section{$3 \quad$ Results and Discussions}

In the context of the quarantine measures introduced due to the COVID-19 pandemic, massive open online courses are a very promising option for obtaining additional knowledge and forming the necessary competencies. As of March 2020, 235 courses were available on the three most well-known Ukrainian online platforms: EdEra (49 courses), Prometheus (130 courses), OUM (56 courses). The courses under study are different in structure, style of giving lecturers and the number of training 
modules. However, they all have the same goal - to give students useful information and develop their competencies.

Let us analyze the developers and thematic focus of online courses on each of these online platforms.

All courses presented on the EdEra educational platform can be divided into seven thematic areas: law, advanced training, education / external independent evaluation (ZNO), media, economics, healthcare, management. Among the developers of online courses are the following institutions and organizations: the Ministries of Ukraine; charitable foundations; online educational platforms; research centers; nongovernmental organizations (NGOs); international organizations; author teams.

It should be noted that institutions and organizations have created a different number of courses depending on the direction of their activities, which is quite understandable. For example, NGOs are interested in the field of "Advanced Training", so they provided information for 5 online courses $(10.2 \%)$. The dependence of the thematic area, the organization-developer and the number of online courses in each of the areas are presented in Table. 1.

Table 1. Number of online courses by thematic areas on the EdEra platform

\begin{tabular}{|c|c|c|c|c|c|c|c|c|}
\hline \multirow{3}{*}{$\begin{array}{c}\text { Developers of online courses } \\
\text { on the platform EdEra }\end{array}$} & \multicolumn{7}{|c|}{ Thematic area } & \multirow{3}{*}{ Total } \\
\hline & Law & \begin{tabular}{|c|} 
Advanced \\
training
\end{tabular} & $\begin{array}{c}\text { Education / } \\
\text { ZNO }\end{array}$ & Media & Economy & \begin{tabular}{|c|} 
Health \\
care
\end{tabular} & $\begin{array}{l}\text { Manage- } \\
\text { ment }\end{array}$ & \\
\hline & \multicolumn{7}{|c|}{ Number of online courses } & \\
\hline Ministries of Ukraine & 1 & 1 & - & -1 & - & - & - & 2 \\
\hline Charitable foundations & - & 1 & - & - & - & - & 1 & 2 \\
\hline Online platforms & 3 & 1 & 12 & 1 & - & 2 & - & 19 \\
\hline Research centres & 1 & - & - & - & - & - & - & 1 \\
\hline NGOs & 1 & 5 & - & - & - & 1 & - & 7 \\
\hline International organizations & 4 & 3 & 3 & 3 & 2 & 1 & - & 16 \\
\hline Author teams & 1 & - & - & - & 1 & - & - & 2 \\
\hline Total & 11 & 11 & 15 & 4 & 3 & 4 & 1 & 49 \\
\hline
\end{tabular}

From the table we can conclude that the most popular thematic areas on the online platform EdEra are law, advanced training and education. Other headings are ancillary, but if necessary, can be used for self-study and certification.

Regarding developers, it can be noted that the most active ones were online educational platforms (Osvitoria, EdEra), on the initiative of which 19 online courses were created $(38.8 \%)$. It is worth noting the electronic resource Osvitoria which created 17 online courses in various fields on the EdEra platform $(34.7 \%)$. The international organizations, in particular IREX, USAID, VOX, Saiup and others, are also actively involved in the creation of courses. With their support, 16 online courses were created, which is $32.7 \%$ of the total number of the online courses presented on the EdEra platform.

On the online platform OUM the situation with thematic areas and developers is different compared to the EdEra platform. This is due to the fact that this project is primarily intended for communities and the general public; it provides education and development of general competencies. We have identified 10 thematic sections: law, 
advanced training, education, media, economics, healthcare, thinking and communication, community, information security, marketing and management.

On this online platform, the information about the developers of the online course is specified in the information block and the certificate is generated after the successful completion of the course. The following organizations took part in the development of online courses on the Ukrainian OUM platform: The Ministry of Healthcare of Ukraine; educational and social centres; non-government organizations, international companies and foundations, author groups. The dependence of thematic areas, development organizations and the number of online courses in each of the areas are presented in Table 2 .

Table 2. Number of online courses by thematic areas on the OUM platform

\begin{tabular}{|c|c|c|c|c|c|c|c|c|c|c|}
\hline \multirow{3}{*}{$\begin{array}{c}\text { Development of online } \\
\text { courses on the OUM } \\
\text { platform }\end{array}$} & \multicolumn{9}{|c|}{ Thematic area } & \multirow{3}{*}{ Total } \\
\hline & Law & $\begin{array}{l}\text { Adv. } \\
\text { training }\end{array}$ & $\begin{array}{c}\text { Educa- } \\
\text { tion/ } \\
\text { Media }\end{array}$ & $\begin{array}{c}\text { Econ } \\
\text { omy }\end{array}$ & $\begin{array}{c}\text { Health } \\
\text { care }\end{array}$ & $\begin{array}{l}\text { Commu- } \\
\text { nication }\end{array}$ & $\begin{array}{c}\text { Com- } \\
\text { munity }\end{array}$ & $\begin{array}{l}\text { Infor- } \\
\text { mation } \\
\text { security }\end{array}$ & $\begin{array}{l}\text { Mar- } \\
\text { keting }\end{array}$ & \\
\hline & \multicolumn{9}{|c|}{ Number of online courses } & \\
\hline $\begin{array}{l}\text { Ministry of Healthcare } \\
\text { of Ukraine }\end{array}$ & - & - & - & - & 2 & - & - & - & - & 2 \\
\hline $\begin{array}{l}\text { Centers, libraries and } \\
\text { offices }\end{array}$ & - & - & 2 & 1 & 1 & - & 2 & - & - & 6 \\
\hline $\begin{array}{l}\text { Companies and labora- } \\
\text { tories }\end{array}$ & 1 & 1 & - & - & - & 1 & 1 & 1 & - & 5 \\
\hline $\begin{array}{l}\text { Online platforms and } \\
\text { portals }\end{array}$ & - & - & 1 & - & - & - & - & 1 & - & 2 \\
\hline $\begin{array}{l}\text { NGOs and charitable } \\
\text { organizations }\end{array}$ & 3 & - & 1 & 1 & - & 2 & 1 & 3 & 1 & 12 \\
\hline Associations & - & - & - & 1 & - & - & 1 & - & - & 2 \\
\hline Author courses & 2 & 1 & 1 & 3 & - & 6 & 2 & - & 6 & 21 \\
\hline $\begin{array}{l}\text { Educational institutions } \\
\text { (schools, universities) }\end{array}$ & 1 & - & - & - & - & - & - & - & 1 & 2 \\
\hline $\begin{array}{l}\text { International funds and } \\
\text { corporations }\end{array}$ & 2 & - & - & - & - & 1 & 1 & - & - & 4 \\
\hline Total & 9 & 2 & 5 & 6 & 3 & 10 & 8 & 5 & 8 & 56 \\
\hline
\end{tabular}

Out of 56 analysed online courses on the OUM platform, 9 law courses were identified, 8 courses on community, marketing and management, 6 courses on economics. 10 courses on the thematic area of "Thinking and Communication" show that people do care what their environment for communication is. In addition, the development of communication and understanding skills is important for students. Regarding the developers, the largest number of courses was created with the support of NGOs and charitable organizations (12 courses / 21.4\%), as well as author teams that created 21 online courses $(37.5 \%)$.

A significant difference in headings and developers can be seen on the Prometheus online platform. Here we have identified 11 thematic areas: law, advanced training, education / external independent evaluation / civic education, media / programming, economics, healthcare, management, communication, English, history, social work. Some topics are tracked on other online platforms. Today, there are six of these top- 
ics: law, advanced training, education / external independent evaluation / civic education, media, economics, healthcare which are relevant among students. The issues of healthcare and financial well-being are the main criteria for everyone to have a comfortable life. The relevance of these educational areas can be explained by the need for lifelong learning and continuous improvement of their own competencies. The direction of the media is explained by the presence of the individual in the social virtual space, in particular social networks, the need to be aware of possible negative influences of social networks, media and more.

The following organizations and institutions were involved in the development of courses on the Prometheus online platform: The Ministries and National Agencies of Ukraine, charitable foundations and organizations; online educational platforms; research centres; non-governmental organizations, international organizations, institutions of higher education, author teams. The generalized data on the thematic areas, organizations-developers and the number of online courses in each of the areas are presented in Table 3.

Table 3. Number of online courses by thematic areas on the Prometheus platform

\begin{tabular}{|c|c|c|c|c|c|c|c|c|c|c|c|}
\hline \multirow{3}{*}{$\begin{array}{l}\text { Development of online } \\
\text { courses on the Prome- } \\
\text { theus platform }\end{array}$} & \multicolumn{10}{|c|}{ Thematic area } & \multirow{3}{*}{ Total } \\
\hline & Law & $\begin{array}{c}\text { Ad- } \\
\text { vanced } \\
\text { training }\end{array}$ & $\begin{array}{l}\text { Edu- } \\
\text { cation } \\
\text { ZNO }\end{array}$ & \begin{tabular}{|c|} 
Media/ \\
Pro- \\
gram- \\
ming
\end{tabular} & $\begin{array}{l}\text { Econ } \\
\text { omy }\end{array}$ & $\begin{array}{l}\text { Healt } \\
\text { hcare }\end{array}$ & $\begin{array}{c}\text { Man } \\
\text { age } \\
\text { ment }\end{array} \mid$ & $\begin{array}{l}\text { Com } \\
\text { muni- } \\
\text { cation }\end{array}$ & $\begin{array}{c}\text { English } \\
\text { lan- } \\
\text { guage }\end{array}$ & \begin{tabular}{|} 
History/ \\
Social \\
work
\end{tabular} & \\
\hline & \multicolumn{10}{|c|}{ Number of online courses } & \\
\hline $\begin{array}{l}\text { Ministries and National } \\
\text { Agencies of Ukraine }\end{array}$ & 2 & 2 & 3 & - & 1 & 1 & - & - & - & - & 9 \\
\hline $\begin{array}{l}\text { Charitable foundations } \\
\text { and organizations }\end{array}$ & 2 & 1 & 7 & 2 & - & - & 1 & 1 & - & 2 & 16 \\
\hline Online-platforms & 2 & - & 7 & 1 & - & 2 & - & & - & - & 12 \\
\hline Research centres & 1 & - & - & - & - & - & - & & - & - & 1 \\
\hline $\begin{array}{l}\text { Non-governmental } \\
\text { organizations }\end{array}$ & 3 & - & - & - & - & 2 & - & & - & - & 5 \\
\hline $\begin{array}{l}\text { International Organiza- } \\
\text { tions }\end{array}$ & 3 & 1 & 6 & 5 & 1 & 2 & - & 3 & 1 & 1 & 23 \\
\hline $\begin{array}{l}\text { Federation of Canadian } \\
\text { Municipalities }\end{array}$ & - & - & - & - & 1 & - & - & & - & - & 1 \\
\hline Author teams & 2 & - & 9 & 7 & 5 & 3 & 1 & 2 & 4 & & 33 \\
\hline $\begin{array}{l}\text { Educational institutions } \\
\text { (schools, universities) }\end{array}$ & 1 & - & 3 & 5 & 4 & - & - & 2 & 1 & 3 & 19 \\
\hline Associations & 2 & & 3 & - & 1 & - & - & - & - & 1 & 7 \\
\hline Artistic Arsenal & - & - & 3 & - & - & - & - & - & - & - & 3 \\
\hline New Post (Nova Poshta) & - & - & - & - & 1 & - & - & - & - & - & 1 \\
\hline Total & 18 & 4 & 41 & 20 & 14 & 10 & 2 & 8 & 6 & 7 & 130 \\
\hline
\end{tabular}

The analysis of the tabular data allowed us to draw certain conclusions. The most active in creating online courses on the Prometheus platform were the author teams that are not employees of higher education institutions (33 courses / 25.4\%), international organizations (23 courses / 17.7\%), institutions of higher and secondary education (19 courses / 14.6\%). 
The analysis of the obtained data presented in Table 1, Table 2, and Table 3 revealed the types of organizations and institutions that participated in the creation or maintenance of online courses on all the three Ukrainian platforms. These include Ministries and National Agencies of Ukraine, charitable foundations and nongovernmental organizations, international organizations, research centres, educational institutions, author groups (table 4).

Table 4. Generalized data on the developers of online courses

\begin{tabular}{|l|c|c|c|c|c|c|c|c|}
\hline \multirow{4}{*}{ Online platform } & \multicolumn{7}{|c|}{ The type of the developer } \\
\cline { 2 - 10 } & $\begin{array}{c}\text { Ministries and } \\
\text { National Agencies } \\
\text { of Ukraine }\end{array}$ & $\begin{array}{c}\text { Charitable } \\
\text { foundations } \\
\text { and NGOs }\end{array}$ & $\begin{array}{c}\text { Interna- } \\
\text { tional } \\
\text { organi- } \\
\text { zations }\end{array}$ & $\begin{array}{c}\text { Research } \\
\text { centers }\end{array}$ & $\begin{array}{c}\text { Educa- } \\
\text { tional } \\
\text { institu- } \\
\text { tions }\end{array}$ & $\begin{array}{c}\text { Online } \\
\text { plat- } \\
\text { forms }\end{array}$ & $\begin{array}{c}\text { Author } \\
\text { teams }\end{array}$ & $\begin{array}{c}\text { Total } \\
\text { courses }\end{array}$ \\
\hline EdEra & 2 & 9 & 16 & 1 & 1 & 19 & 2 & 50 \\
\hline Prometheus & 9 & 17 & 23 & 6 & 19 & 12 & 30 & 114 \\
\hline OUM & 2 & 12 & 4 & 1 & 2 & 2 & 21 & 44 \\
\hline Total & 13 & 38 & 43 & 8 & 22 & 33 & 53 & 210 \\
\hline
\end{tabular}

Table 4 shows that the development of 50 courses $(89 \%$ of the total number of courses presented on the EdEra platform) involved organizations that developed online courses on other educational platforms. On the Prometheus platform, the number of such courses is $114(87.7 \%$ of the total number of courses presented on the platform). On the OUM platform, this percentage is 44 (79\% of the total number of the courses presented on the platform). The rest of the online courses ( 25 online courses, $6.4 \%$ of the total number of courses) were created by the developers who did not fall into any category.

The largest number of online courses was created by author teams (53 courses), which is $22.6 \%$ of the total number of the developed courses on the three platforms (235 courses). The least number ( 8 courses) was developed by research centres, which is $3 \%$ of the total number of the courses presented on the Ukrainian online platforms.

\section{Conclusion}

Thus, massive open online courses are one of the promising and effective open electronic resources for additional education. They provide the acquisition of the necessary competencies and useful information on various topics. The areas of the MOOC promotion include ensuring a quality relationship between teachers and students, improving the assessment system, increasing the motivation to acquire knowledge, acceptance of the results of the completed course as an informal element at the legislative level.

As of March 2020, 235 courses were available on the Ukrainian platforms EdEra, Prometheus, OUM. The largest number of courses was created on the Prometheus platform (130 courses), the least number of the courses - on the EdEra (49 courses).

The main thematic areas on the EdEra platform are law, advanced training, education / external independent evaluation, media, economics, healthcare, management. 
The main thematic areas on the Prometheus platform are law, advanced training, education / external independent evaluation / civic education, media / programming, economics, healthcare, management, communication, English, history, social work. The main thematic areas on the OUM platform are law, advanced training, education, media, economics, healthcare, thinking and communication, community, information security, marketing and management. The same topics for all platforms are law, advanced training, education, media, economy, and healthcare.

The development and support of online courses on various platforms are provided by the Ministries and National Agencies of Ukraine (13 courses, 5.5\%), charitable foundations and non-governmental organizations (38 courses, 16.2\%), international organizations (43 courses, 18.3\%), research centres (8 courses, 3.4\%), educational institutions (22 courses, 9.4\%), online platforms (33 courses, 14\%), author teams (53 courses, $22.6 \%$ ). They are actively working on the content of electronic educational portals and platforms. Various institutions and organizations reproduce information to some extent within their capabilities and the field of activity.

The most active developers of online courses for the OUM platform are nongovernmental and charitable organizations, which have created 12 courses $(21.4 \%)$. The most active developers on the EdEra platform were educational online platforms, on the initiative of which 19 online courses were created $(38.8 \%)$, and international organizations, with the help of which 16 online courses were created $(32.7 \%)$. The largest number of courses on the Prometheus platform was created with the support of international organizations (23 courses / 17.7\%), institutions of higher and secondary education (19 courses / 14.6\%). The organizations involved in the development of online courses gain prestige and reputation among similar institutions.

The Ukrainian online platforms are focused on creating their own educational content. They are periodically updated with new courses which increase the number of thematic areas.

\section{$5 \quad$ References}

[1] Tkachuk, V. et al. (2020). WebAR development tools: comparative analysis. Physical and Mathematical Education, 2(24): 159-167. (in Ukrainian). https://dx.doi.org/10.31110/24131571-2020-024-2-021

[2] Gorbatyuk, R. (2013). Mobile education as a new technology of higher education. Scientific herald of the Uzhhorod University: Series: Pedagogy. Social work, 27: 31-34. (in Ukrainian).

[3] Kukharenko, V. (2015). System approach to blended learning. Information technologies in education, 24: 53-67. (in Ukrainian). https://dx.doi.org/10.14308/ite000550

[4] Suartama, I.K. et al. (2020). Development of Ubiquitous Learning Environment Based on Moodle Learning Management System. International Journal of Interactive Mobile Technologies, 14(14): 182-204. https://doi.org/10.3991/ijim.v14i14.11775

[5] Sharov, S., Liapunova, V., Sharova, T. (2019). Analysis of the Opportunities of the Prometheus Platform for the Professional Development of Future Teachers. TEM Journal, 8(4): 1469-1476. https://doi.org/10.18421/TEM84-52 
[6] Kolesnyk, L. (2019). Trends in the use of massive open online courses in the training of primary education specialists. Pedagogical sciences: theory, history, innovative technologies, 3(87): 62-72. (in Ukrainian). https://dx.doi.org/10.24139/2312-5993/2019.03/062-072

[7] Adamova, I., Golovachuk, T. (2012). Distance learning: a modern view of the advantages and problems. Origins of pedagogical skills. Series: Pedagogical sciences, 10: 3-6. (in Ukrainian).

[8] Shyshkina, M., Spirin, O., Zaporozhchenko, Yu. (2012). Problems of Informatization of Education in Ukraine in the Context of Development of Research of ICT-Based Tools Quality Estimation. Information Technologies and Learning Tools, 27(1). (in Ukrainian). https://doi.org/10.33407/itlt.v27i1 https://doi.org/10.33407/itlt.v27i1.632

[9] Antonova, O., Familyarska, L. (2019). The use of digital technologies in the educational environment of a higher education institution. Open educational e-environment of a modern university, special edition: 10-22. (in Ukrainian). https://doi.org/10.28925/2414$\underline{0325.2019 \mathrm{~s} 2}$

[10] Smolina, I., Shchetinina, O. (2018). Organization of independent work of students with the use of massive open online courses. Problems of engineering and pedagogical education, 58: 78-84. (in Ukrainian). https://doi.org/10.32820/2074-8922-2018-58-78-84

[11] Fidalgo, P. et al. (2020). Students' perceptions on distance education: A multinational study. International Journal of Educational Technology in Higher Education, 17: 1-18.

[12] McGreal, R. (2012). The need for Open Educational Resources for ubiquitous learning. 2012 IEEE International Conference on Pervasive Computing and Communications Workshops. IEEE, 2012, 679-684. https://doi.org/10.1109/percomw.2012.6197600

[13] Kravtsov, G., Vinnyk, M., Tarasich Yu. (2013). Research of influence of quality of electronic educational resources on quality of educational services with use of distance learning technologies. Information technologies in education, 16: 83-94. (in Ukrainian). https:// doi.org/10.14308/ite000431

[14] Golitsyna, I. (2017). Educational process in electronic information-educational environment. Procedia-Social and Behavioral Sciences, 237: 939-944. https://doi.org/10.1016/j.sbs pro.2017.02.132

[15] Johnstone, S. (2005). Open educational resources serve the world. Educause Quarterly, 3(28): 15.

[16] Hilton III, J. (2016). Open educational resources and college textbook choices: a review of research on efficacy and perceptions. Educational Technology Research and Development, 64(4): 573-590. https://doi.org/10.1007/s11423-016-9434-9

[17] Alameen, A., Dhupia, B. (2019). Implementing Adaptive e-Learning Conceptual Model: A Survey and Comparison with Open Source LMS. International Journal of Emerging Technologies in Learning, 14(21): 28-45. https://doi.org/10.3991/ijet.v14i21.11030

[18] Pavlenko, O. et al. (2019). Implementation of the distance learning by Moodle platforms in the process of future philologists training. Engineering and Educational Technologies, 7(3): 106-121. (in Ukrainian).

[19] Kuzmenko, G., Khorolsky, O. (2015). Massive open online courses in the context of transformation of higher education in Ukraine. Pedagogical sciences, 63: 56-61. (in Ukrainian).

[20] Vakalyuk, T. (2018). Selection of massive open online courses for use in the preparation of bachelors of computer science. Scientific Bulletin of Melitopol State Pedagogical University. Series: Pedagogy, 1: 128-133. (in Ukrainian).

[21] Romero, C., Ventura, S. (2017). Educational data science in massive open online courses. Wiley Interdisciplinary Reviews: Data Mining and Knowledge Discovery, 7(1): 1187. https://doi.org/10.1002/widm.1187 
[22] Dobrovolska, S., Opyr, M., Myronenko, N., Panchyshyn, S. (2019). Massive open online courses as an alternative form of higher education. Scientific Bulletin of Melitopol State Pedagogical University. Series: Pedagogy, 2(23): 29-35. https://doi.org/10.33842/221952 $\underline{03 / 2019 / 23 / 29 / 35}$

[23] Gamage, D., Perera, I., Fernando, S. (2020). Exploring MOOC User Behaviors Beyond Platforms. International Journal of Emerging Technologies in Learning, 15(8): 161-179. https://doi.org/10.3991/ijet.v15i08.12493

[24] Yuan, L., Powell, P. MOOCs and open education: Implications for higher education. https ://doi.org/10.13140/2.1.5072.8320

[25] Husain, H., Thalib, S., Ahmad, A., Anshar, A. (2019). Development of Analog-Based Online Electronic Learning Models in Improving Students Learning Outcomes in Informatics Engineering Study Programs. TEM Journal. 8(1): 284-289. https://doi.org/10.184 21/TEM81-39

[26] Sharov, S. (2019). Use of EdEra online platforms for professional training of future teachers of Ukrainian language and literature. Pedagogical sciences: theory, history, innovative technologies, 2(86): 119-128. (in Ukrainian).

[27] Osetsky, V., Tatomyr, I. (2017). The role of massive open online courses in the modern educational landscape. Economy of Ukraine, 12: 86-98. (in Ukrainian).

\section{Authors}

Sharov Sergii is PhD of Pedagogical Sciences, Associate professor, Associate professor of the Department of Ukrainian and foreign literature of Bogdan Khmelnitsky Melitopol State Pedagogical University, Getmanska Str., 20, Melitopol, Ukraine. The author's research interests include the use of ICT in high school, massive open online courses, programming, social competence of students.

Anatolii Pavlenko is a Doctor of Pedagogical Sciences, professor of the Department of social work of Khortytsia National Educational and Rehabilitation Academy, Naukove Mistechko Str. (Khortytsia Island), 59, Zaporizhzhia, Ukraine. His academic interest in the field of pedagogy, theory of solving and compiling, education tasks and problems, education sociology, teacher education.

Tetiana Sharova is $\mathrm{PhD}$ of Philological Sciences, Associate professor, Associate professor of the Department of Ukrainian and foreign literature of Bogdan Khmelnitsky Melitopol State Pedagogical University, Getmanska Str., 20, Melitopol, Ukraine. Her academic interest in the field of philology, pedagogy, application of ICT in higher education.

Olga Chorna is $\mathrm{PhD}$ of Pedagogical Sciences, Associate professor of the Department of Foreign Languages of Bogdan Khmelnitsky Melitopol State Pedagogical University, Getmanska Str., 20, Melitopol, Ukraine. Her academic interest in the field of English methodology, pedagogy and social competence of students in high school.

Article submitted 2020-09-15. Resubmitted 2020-12-01. Final acceptance 2020-12-01. Final version published as submitted by the authors. 